\title{
To the Question of the Interference and Positive Transfer When Teaching Russian to Hispanic Students
}

\author{
Dinara Rashidovna Valeeva ${ }^{1} \&$ Alina Andreevna Ershova ${ }^{1}$ \\ ${ }^{1}$ Kazan Federal University, Russia \\ Correspondence: Dinara Rashidovna Valeeva, Kazan Federal University, Russia. E-mail: mega.sppa@mail.ru \\ Received: July 17, 2019 \\ Accepted: October 15, 2019 \\ Online Published: October 28, 2019 \\ doi:10.5430/ijhe.v8n7p39 \\ URL: https://doi.org/10.5430/ijhe.v8n7p39
}

\begin{abstract}
The real research is devoted to problems of an interlingual interference in the process of studying of Russian by students of the Hispanic countries. The relevance of the article is caused by the fact that at all variety of the scientific works devoted to the contrast description of various languages and the analysis of their interference, it is a little work comparing the Russian and Spanish languages. The research was conducted for the purpose of comparison of the separate language phenomena of the Russian and Spanish languages and the description of those lexical and grammatical features which knowledge will allow teachers to warn and correct native speaker errors in the Russian speech, therefore, to optimize training process. According to the authors, it is advisable to use the national focused tests and tasks on classes in RKI and also governed with explanations and examples in the native language of students that will increase their intellectual activity.
\end{abstract}

Keywords: interlingual interference, positive transfer, Russian as foreign, Spanish, training

\section{Introduction}

In the course of training in a foreign language, each teacher faces that students try to find a literal translation of a concrete lexeme and to correlate this or that grammatical construction with similar in the native language. In one case it conducts to interferential mistakes, and in others - simplifies the understanding of a new subject and accelerates the formation of skills of speaking and the letter. In this regard, the research of interfering influence of the native speech of the students mastering a foreign language seems relevant.

The purpose of this article - to characterize the phenomena of an interlingual interference and positive transfer in the course of training a Hispanic native speaker in Russian. The novelty of article is caused by the fact that at all variety of the scientific works devoted to the contrast description of various languages and the analysis of their interference, the works comparing the Russian and Spanish languages it is a little of (Pshenichnikova, A. Yu, 2014) (Vinogradova, O. M., 2015) (Petrova, N. M. , 2016) (Golikov, S. N., 216) (Mironova, D. M., 2017).

\section{Methods}

For the achievement of the object set in work, the following methods and receptions of research are used: the descriptive method including observation, interpretation, generalization, and classification of the analyzed material; functional method; comparative.

When writing the article by authors scientific and pedagogical works of domestic and foreign scientists in the field of a technique of teaching languages and also data of explanatory dictionaries and basic word stocks on Russian as foreign were used.

\section{Results and Discussion}

It is known that the term "interference" began to be used actively in linguistic science thanks to researches of U. Vaynraykh who considered an interference as a deviation from language norms in the speech of bilinguals under the influence of another foreign language (Vaynraykh, A. T., 1979). Many modern scientists adhere to this position (Bobko, P. A., 2017).

The interference is considered, as a rule, as the negative phenomenon leading to phonetic, lexical, grammatical, stylistic violations in the speech of students and written that when training in a foreign language it is necessary to overcome its negative impact (Jenkins, J., 2000)(Korzhaeva, Ju. S., 2014)(Yusupova, Z. F., 2014)(Abidova, R. Kh., Yusupova, Z. D., Ibodullayeva, D., \& Ashirboyeva, M., 2015)(Nikishina, S. R., \& Yarullina, A. Sh., 
2017)(Hackett-Jones, A. V., 2016)(Sandibayeva, D., \& Norkuziyeva, I., 2016)(Hermans, D., Bongaerts, T., De bot K., \& Schreuder, R., 1998)(Kharisov, F. F., Shakurova, M. M., \& Mirzagitov, R. H., 2015)(Braet, W., Wagemans, J., Op de Beeck H., \& Noppe, N., 2011).

Authors of the article also consider that an interference - negative transfer of speech skills from the native language on studied and it arises at various language levels: phonetic, lexico-semantic, morphological, syntactic, etc. As well as most researchers, authors believe that the interfering influence of the native language can lead to numerous mistakes, in particular when languages belong to different families.

Let's consider the interference phenomenon in more detail on the example of the interaction of the Spanish and Russian languages. So, one of the frequency lexico-semantic mistakes characteristic of Hispanic students, not distinction and mixture in the speech of the verbs "be able", "can" and "know" is. Correspond to them in Spanish of the word "saber", "poder" and "conocer" which use, however, significantly differs from Russian. For example, for designation of ability or constant ability (or its absence) in Spanish the verb "saber" (Kuznetsov, S. A., 2000) is used while in Russian - "to be able". Students quite often abuse literal translation that involves wrong phrases like "I know to play chess". Besides, for information transfer about the familiar person the verb "conocer" serves in Spanish, and in Russian to it there corresponds "know" (for example, "the knowledge of the neighbor personally") (Diccionario de la lengua Española, 2001) that also complicates speech activity.

To reduce the quantity of the similar mistakes made by Spanish-speaking students the creation of the national focused tests and exercises (table 1) is advisable. They can be preceded by small capacious comments, some kind of references, in the native language of students with examples and the translations (table 2).

Table 1. Differentiation and use of the verbs "know", "can", "be able" (tests)

\begin{tabular}{|c|c|}
\hline 1. I ... Petr well. We studied at one school. & $\begin{array}{l}\text { A. know } \\
\text { Б. can } \\
\text { B. be able }\end{array}$ \\
\hline 2. Mark and Olga already all ... about accident. I told them. & $\begin{array}{l}\text { A. know } \\
\text { Б. can } \\
\text { B. be able }\end{array}$ \\
\hline 3. Do you ... to drive the car? & $\begin{array}{c}\text { A. know } \\
\text { Б. can } \\
\text { B. be able }\end{array}$ \\
\hline 4. ... you come visit during weekend? & $\begin{array}{l}\text { A. know } \\
\text { Б. can } \\
\text { B. be able }\end{array}$ \\
\hline 5. My wife never ... how to cook. & $\begin{array}{l}\text { A. know } \\
\text { Б. can } \\
\text { B. be able }\end{array}$ \\
\hline
\end{tabular}


Table 2. The verbs "know", "be able", "can" in Russian and their correlates in Spanish (rule)

\begin{tabular}{|c|c|c|c|}
\hline $\begin{array}{l}\text { Verb in } \\
\text { Russian }\end{array}$ & $\begin{array}{l}\text { Verb in } \\
\text { Spanish }\end{array}$ & Examples & Explanation \\
\hline Know & Conocer & $\begin{array}{c}\text { I know Miguel. = Conozco a } \\
\text { Miguel. } \\
\text { - I know biology well. = } \\
\text { Sé_bilología muy bien. } \\
\text { - I know about the } \\
\text { exam. = Sé sobre los } \\
\text { examines. }\end{array}$ & $\begin{array}{c}\text { El verbo "know" significa que hemos tenido } \\
\text { alguna experiencia de la persona conocida. } \\
\text { - El verbo "know" se usa cuando } \\
\text { alguien tiene conocimiento, ideas } \\
\text { sobre una ciencia o materia. } \\
\text { - El verbo "know" se usa para hablar de } \\
\text { conocimiento que una persona se tiene } \\
\text { o no se tiene de una información o } \\
\text { noticia. }\end{array}$ \\
\hline Can & Saber & $\begin{array}{l}\text { He can swim. = Ella sabe nadar. } \\
\text { He can write and read in Russian. } \\
\text { = Él sabe escribir y leer ruso. }\end{array}$ & $\begin{array}{c}\text { El verbo “can” se utiliza para hablar de } \\
\text { habilidades aprendidas y significa que alguien } \\
\text { está instruido en algo. }\end{array}$ \\
\hline Be able & Poder & $\begin{array}{l}\text { I am able to help you. = Puedo } \\
\text { ayudarte. I am able to meet you at } \\
\text { the airport. = Puedo encontrarte } \\
\text { en el aeropuerto. }\end{array}$ & $\begin{array}{c}\text { El verbo "be able" se parece al verbo "poder" en } \\
\text { español y se utiliza para expresar la posibilidad o } \\
\text { capacidad de hacer algo. }\end{array}$ \\
\hline
\end{tabular}

In the course of studying Russian, there is not only negative interfering impact of native Spanish but also positive. This phenomenon received the name of a transferention, or transfer. Its essence is that having faced a new task, the person tries to use at first such receptions which he owns (Gural, S. K., \& Sorokina, E. I., 2012). The positive transfer can be used on occupations, for example, an acquaintance to parts of speech and their grammatical categories. Let's illustrate it on the example of the category of a sort of the Russian nouns. Certainly, the native language will exert interfering impact on the formation of new skills at students, this category in Spanish significantly differs from similar in Russian that leads to mistakes, and first of all at the elementary level of studying of RKI. First, in Russian three sorts (men's, women's and average), while in Spanish two (the category of a neutral gender is absent). Secondly, in languages, there are identical terminations peculiar to different patrimonial categories: about - for a neutral gender in Russian and about - for a masculine gender in Spanish (Golikov, S. N., 2016). Thirdly, in Russian special difficulties cause the words which are coming to an end on the soft sign and not giving in to concrete rules (a notebook, church - a feminine gender; the dictionary, a root - a masculine gender), except for nouns with a suffix - a tel and names of months (all of them a masculine gender). During the occupations students often have difficulties in coordination of adjectives and possessive pronouns with nouns on-. As practice and the analysis of requirements for Russian as foreign shows, noun gender, included in basic word stocks elementary, basic and the I certified levels, as a rule, coincides with a sort of their correlates in Spanish therefore, in our opinion, on classes in RKI with Hispanic listeners it is possible to tell about such phenomenon, and the words differing in a sort, to give as an exception to the rules that will simplify storing of new lexicon, formation, and fixing of grammatical skills and will allow avoiding potential mistakes in the speech of students (examples are given in the table number 3 ). 
Table 3. Noun gender on -ь in Russian and a sort of their correlates in Spanish

\begin{tabular}{ccc}
\hline \multicolumn{2}{c}{ Coincidence in noun gender } & Discrepancy \\
\hline Nouns & Nouns & in noun gender \\
masculine gender & feminine gender & Roor - puerta \\
\hline Guest - huésped & News - novedad, noticia & Love - el amor \\
Day - día & Help - ayuda & Notepad - el cuaderno \\
inhabitant - habitante & Salt - sal & Fall - el otoño \\
Vocabulary - diccionario & Painting - pintura & Cost - el coste, el valor \\
Teacher - maestro & Youth - juventud & Cose - el objetivo \\
Ruble - rublo & Church - iglesia & Caugh - la tos \\
Hotel - hotel & Thing - cosa & Pain - el dolor \\
Boat - barco & Net - red & \\
& & \\
\hline
\end{tabular}

\section{Summary}

So, one of the reasons for mistakes which arise at students on classes in Russian as foreign is the language interference representing a negative transfer of speech skills from the native language on studied. The interference can arise at various language levels. In this article we considered some questions of a lexical and grammatical interference and on the example of comparison of the verbs "know", "can", "be able" and "saber", "poder", "conocer" and also categories of noun gender in the Russian and Spanish languages showed that for the purpose of overcoming an interference in training it is possible to use the national focused tests and tasks and also governed with explanations and examples in the native language of students. According to authors of the article, it will allow an optimizing process of training and will increase the intellectual activity of students who will learn to compare and analyze the lexical and grammatical phenomena of the Russian and Spanish languages. Besides, at all divergence of these or those language phenomena it is possible to establish lines of similarity, even when languages, such as Russian and Spanish, belong to different language families, and positive transfer, certainly, will accelerate and will simplify the process of formation and fixing of language skills on the creation of statements in nonnative language.

\section{Conclusions}

Summing up the result, it is necessary to notice that the subject of interference and a transferention of the Russian and Spanish languages is studied insufficiently and demands further consideration. Carrying out parallels with the native language of students as it is one of important linguo-didactic means when training in a foreign language, in particular to Russian as foreign is represented perspective.

\section{Acknowledgments}

The work is performed according to the Russian Government Program of Competitive Growth of Kazan Federal University.

\section{References}

A basic word stock on Russian as foreign. (2000). Elementary level. General possession. N.P. Andryushina, T.V. Kozlova. - M.: - SPb: TsMO MSU - Zlatoust, - 80

A basic word stock on Russian as foreign. (2011). Basic level. The general possession. N.P. Andryushina, etc. - 4 ed. revised - M.: SPb.: TsMO MSU, Zlatoust, 116

A basic word stock on Russian as foreign. (2011). I certified level. The general possession. N.P. Andryushina, etc. 5 ed. revised - SPb.: Zlatoust, 200

Abidova, R. Kh., Yusupova, Z. D., Ibodullayeva, D. \& Ashirboyeva, M. (2015). Interference of mother tongue in teaching and learning foreign languages, Eurpean Journal of Literature and Linguistics, 3, 3-5.

Braet, W., Wagemans, J., Op de Beeck H. \& Noppe, N. (2011). Increased stroop interference with better second-language reading skill, The Quarterly Journal of Experimental Psychology, 64(3), 596-607.

Bobko, P. A. (2017). Language interference. European scientific conference, 58-59. 
Diccionario de la lengua española. (2001). 22 edición. Real Academia Española. URL: http://dle.rae.es/

Eisvandi, M., Gorji, Y. \& Niknejadi, F. (2015). Effectiveness of Emotional Intelligence on Increasing the Psychological Dimension of Quality of Life of Mothers of Educable Mentally Retarded Children in Esfahan in, UCT Journal of Social Sciences and Humanities Research, 3(1), 29-31.

Feizuldayeva, S., Ybyraimzhanov, K., Mailybaeva, G., Ishanov, P., Beisenbaeva, A. \& Feizuldayeva, S. (2018). Vocational training of future elementary school teacher by means of realization of inter-subject continuity, Opción, 34(85-2), 479-516.

Golikov, S. N. (2016). The nationally focused conclusions recommendations having practical value for teachers-specialists in Russian philology on occupations in Spanish-speaking audience. Philological sciences, Questions of the theory and practice, 10-1(64), 176-186.

Gural, S. K. \& Sorokina, E. I. (2012). Interferential language phenomena and positive transfer (English, French and Italian languages), Bulletin of the Tomsk state university, 354, 7-11.

Hermans, D., Bongaerts, T., De bot K. \& Schreuder, R. (1998). Producing words in a foreign language: can speakers prevent interference from their first language?, Bilingualism: Language and Cognition, 1(3), 213-229.

Hackett-Jones, A. V. (2016). Language and culture interference in plurilingual education, Russian linguistic Bulletin, 3(7), 141-143.

Jenkins, J. (2000). The phonology of English as an International language. Oxford: Oxford University Press, 258

Korzhaeva, Ju. S. (2014). The overcoming of the interference of Russian language in foreign language education, The First International Conference on Eurasian scientific development, 152-156.

Kharisov, F. F., Shakurova, M. M. \& Mirzagitov, R. H. (2015). Native language effect in teaching Tatar as a second language and the ways to overcome language interference, Journal of Language and Literature, 6(2), 460-463.

Kuznetsov, S. A. (2000). Big explanatory dictionary of Russian. - SPb.: Norint, 1536,

Mironova, D. M. (2017). Role of the comparative analysis in the cognitive focused technique of teaching RKI, News of Southern Federal University, 4, 221-229.

Machado, A. D. B., Souza, M. J. \& Catapan, A. H. (2019). Systematic Review: Intersection between Communication and Knowledge, Journal of Information Systems Engineering \& Management, 4(1).

Nikishina, S. R. \& Yarullina, A. Sh. (2017). Language interference in the teaching of a foreign language, World Science Proceedings of articles the international scientific conference, 292-295.

Peranginangin, S. A., Saragih, S. \& Siagian, P. (2019). Development of Learning Materials through PBL with Karo Culture Context to Improve Students' Problem Solving Ability and Self-Efficacy, International Electronic Journal of Mathematics Education, 14(2), 265-274. https://doi.org/10.29333/iejme/5713

Pshenichnikova, A. Yu. (2014). On forecasting phonetic mistakes when training Spanish speaking students, New pedagogical technologies, 17, 75-78.

Petrova, N. M. (2016). A language interference of the Latin American option when training in Russian as foreign, Technique of teaching foreign languages: traditions and innovations, 113-119.

Sandibayeva, D. \& Norkuziyeva, I. (2016). The ways of preventing interference in teaching foreign language, Ученыгй ХХІ века, 5-2(18), 37-39.

Vinogradova, O. M. (2015). Accounting of the native language when training Hispanic students. Bulletin of the Tver state technical university, "Sciences about Society and the Humanities" series, 3, 111-114.

Vaynraykh, A. T. (1979). Language contacts. - Kiev: Higher School publishing house, 263

Yusupova, Z. F. (2014). Ways to overcome the cross-language interference at teaching Turkic-speaking attendance in the Russian language, Life Science Journal, 11(9), 366-369. 